Fitriatin, B.N. • M.I.M. Yusuf · A. Nurbaity · N.N. Kamaluddin • M. Rachmady $\cdot$ E.T. Sofyan

\title{
Serapan nitrogen dan fosfor serta hasil jagung yang dipengaruhi oleh aplikasi pupuk hayati dengan berbagai teknik dan dosis pada tanah Inceptisols
}

Sari. Upaya meningkatkan unsur hara nitrogen $(\mathrm{N})$ dan fosfor $(\mathrm{P})$ tanah secara berkelanjutan adalah dengan memanfaatkan agen hayati bakteri penambat nitrogen dan bakteri pelarut fosfat. Percobaan pot dilakukan dengan tujuan untuk menentukan teknik aplikasi pupuk hayati dalam meningkatkan kandungan dan serapan hara N dan P serta hasil tanaman jagung pada Inceptisols Jatinangor. Percobaan dilaksanakan di Lahan Percobaan milik Laboratorium Kesuburan Tanah dan Nutrisi Tanaman, Fakultas Pertanian Universitas Padjadjaran. Pupuk hayati yang digunakan merupakan konsorsium bakteri penambat N (Azotobacter chroococcum dan Azospirillum sp.) dan bakteri pelarut P (Pseudomonas malei dan Bacillus subtillis). Percobaan menggunakan Rancangan Acak Kelompok (RAK) dengan sembilan perlakuan dan tiga ulangan. Perlakuan terdiri dari tanpa aplikasi pupuk hayati (kontrol); aplikasi pupuk hayati menggunakan perlakuan benih dengan dosis $500 \mathrm{~g}$ dan $250 \mathrm{~g} / \mathrm{ha}$; aplikasi pupuk hayati ke dalam tanah dengan dosis $50 \mathrm{~kg}$ dan $25 \mathrm{~kg} / \mathrm{ha}$; dan kombinasi antara perlakuan benih dan aplikasi ke dalam tanah. Hasil percobaan menunjukkan bahwa teknik aplikasi pada benih, pada tanah, dan kombinasinya meningkatkan serapan N dan P serta hasil tanaman jagung. Perlakuan pupuk hayati pada benih $500 \mathrm{~g} / \mathrm{ha}$ + aplikasi pada tanah $50 \mathrm{~kg} /$ ha merupakan perlakuan terbaik dalam meningkatkan serapan $\mathrm{N}$ sebesar $51 \%$ dan serapan P hingga 90\% dibandingkan kontrol. Perlakuan pada benih $250 \mathrm{~g} / \mathrm{ha}+$ aplikasi pada tanah $25 \mathrm{~kg} /$ ha merupakan perlakuan terbaik dalam meningkatkan hasil sebesar 56\% dibandingkan kontrol. Teknik aplikasi pupuk hayati yang efisien dapat digunakan untuk meningkatkan produksi tanaman jagung.

Kata kunci: Aplikasi tanah $\cdot$ Keamanan pangan $\cdot$ Pelarut fosfat $\cdot$ Penambat nitrogen Perlakuan benih

\section{Nitrogen and phosphorus uptake and yield of maize affected by different technique and doses of biofertilizers application on Inceptisols}

\begin{abstract}
The application of biological agents such as nitrogen fixing bacteria and phosphate solubilizing bacteria is an effort to increase soil nitrogen $(\mathrm{N})$ and phosphorus $(\mathrm{P})$ content. Pot experiment aimed to determine the best application technique of biofertilizer to increase $\mathrm{N}$ and $\mathrm{P}$ uptake and the yield of maize on Inceptisols. The experiment was carried out at the experimental field of the Laboratory of Soil Fertility and Plant Nutrition, Faculty of Agriculture, Universitas Padjadjaran. Biofertilizers contained of $\mathrm{N}$-fixing bacteria (Azotobacter chroococcum and Azospirillum sp.) and phosphate solubilizing bacteria (Pseudomonas malei and Bacillus subtillis). The experiment used a randomized block design with nine treatments and three replications. The treatments consisted of without biofertilizer application (control); biofertilizers application to seed (seed treatment) at a dose of $500 \mathrm{~g} \mathrm{ha}^{-1}$ and $250 \mathrm{~g} \mathrm{ha}^{-1}$; biofertilizers application to the soil (soil treatment) with a dose of $50 \mathrm{~kg} \mathrm{ha}^{-1}$ and $25 \mathrm{~kg} \mathrm{ha}^{-1}$; and the combinations between seed treatment and soil treatment. The results showed that the application of seed treatment, soil treatment, and their combination increased $\mathrm{N}$ and $\mathrm{P}$ uptake and yields of maize. The seed treatment at a dose of $500 \mathrm{~g} \mathrm{ha}^{-1}+$ soil treatment at a dose of $50 \mathrm{~kg} \mathrm{ha}^{-1}$ were the best treatment for increasing $\mathrm{N}$ uptake by $51 \%$ and $\mathrm{P}$ uptake by $90 \%$ compared to control. The seed treatment at a dose of $250 \mathrm{~g} \mathrm{ha}^{-1}+$ soil treatment at a dose of $25 \mathrm{~kg} \mathrm{ha}^{-1}$ increased yield of maize by $56 \%$ (213.40 g). Efficient biofertilizer application techniques could be used to increase maize production.
\end{abstract}

Keywords: Soil application · Food security $\cdot$ Phosphate solubilizing $\cdot$ Nitrogen fixing $\cdot$ Seed treatment

Diterima : 23 Juni 2021, Disetujui : 8 Desember 2021, Dipublikasikan : 15 Desember 2021

DOI: $\underline{10.24198 / \text { kultivasi.v20i3.34107 }}$

\footnotetext{
Fitriatin, B.N. ${ }^{1}$ M.I.M. Yusuf ${ }^{2}$ A. Nurbaity ${ }^{1}$ N.N. Kamaluddin ${ }^{1}$ - M. Rachmady ${ }^{3}$ E.T. Sofyan ${ }^{1}$

${ }^{1}$ Dept. Ilmu Tanah dan Sumberdaya Lahan, Fak. Pertanian Unpad, Jl. Raya Bandung Sumedang Km. 21 Jatinangor, Sumedang 45363

2 Program Studi Agroteknologi, Fak. Pertanian Unpad, Jalan Raya Bandung Sumedang Km. 21 Jatinangor, Sumedang 45363

${ }^{3}$ Dept. Budidaya Tanaman, Fak. Pertanian Unpad. Jalan Raya Bandung Sumedang Km. 21 Jatinangor, Sumedang 45363

Korepondensi: betty.natalie@unpad.ac.id
}

Fitriatin, B.N. $d k k$ : : Serapan nitrogen dan fosfor serta hasil jagung yang dipengaruhi oleh aplikasi pupuk hayati dengan berbagai teknik dan dosis pada tanah Inceptisols 


\section{Pendahuluan}

Jagung merupakan salah satu komoditas yang selain menjadi pangan pokok bagi beberapa penduduk di wilayah Indonesia, juga merupakan bahan pakan utama peternakan unggas serta menjadi bahan baku industri olahan. Produksi jagung dapat ditingkatkan dengan teknologi yang aman dan ramah lingkungan untuk menjamin keamanan pangan, salah satunya dengan pemanfaatan sumber daya hayati, yaitu penggunaan pupuk hayati. Pupuk hayati merupakan substansi yang mengandung mikroba hidup yang mengkolonisasi rhizosfer atau bagian dalam tanaman yang berfungsi memacu pertumbuhan tanaman dengan jalan meningkatkan ketersediaan hara (Macik et al., 2020). Bhardwaj et al. (2014) menerangkan isolat mikroba yang dapat digunakan sebagai pupuk hayati diantaranya mikroba pelarut fosfor $(\mathrm{P})$, bakteri penambat nitrogen $(\mathrm{N})$, mikoriza, dan bakteri pemacu tumbuh.

Bakteri pemfiksasi nitrogen (BPN) merupakan kelompok bakteri yang mampu mengkonversi nitrogen dari atmosfir menjadi amonia. Bakteri ini dapat tumbuh bebas di rhizosfer tanaman (non-simbiotik) atau yang bersimbiosis dengan tanaman. Bakteri Azotobacter merupakan penambat gas $\mathrm{N}_{2}$ yang mampu menghasilkan substansi zat pemacu tumbuh giberelin, sitokinin, dan asam indol asetat, sehingga pemanfaatannya dapat memacu pertumbuhan akar (Sumbul et al., 2020).

Mikroba pelarut fosfat (MPF) merupakan kelompok mikroba tanah yang mempunyai kemampuan mengekstraksi $\mathrm{P}$ dari ikatan dengan $\mathrm{Al}, \mathrm{Fe}, \mathrm{Ca}$, dan $\mathrm{Mg}$, sehingga dapat melarutkan $\mathrm{P}$ yang asalnya tidak tersedia bagi tanaman menjadi tersedia bagi tanaman (Walpola and Yoon, 2013). Hal ini terjadi karena mikroba tersebut mengeluarkan asam-asam organik yang dapat membentuk kompleks stabil dengan kation-kation pengikat $\mathrm{P}$ di dalam tanah (Rashid et al., 2004; Li et al., 2019).

Tanah yang banyak terdapat hampir di sebagian besar wilayah di Indonesia adalah tanah ordo Inceptisol. Terdapat 52,0 juta Ha Inceptisols tersebar di Indonesia yang berpotensi untuk dikembangkan (Kasno, 2009). Budidaya jagung di tanah Inceptisol memiliki beberapa masalah karena tanah Inceptisol memiliki kesuburan tanah dan bahan organik yang rendah, dan memiliki reaksi tanah masam
(Abdurachman, 2008). Keefektifan pupuk hayati dalam mendukung pertumbuhan dan perkembangan tanaman di tanah Inceptisol dipengaruhi oleh kualitas isolat, serta kualitas dan komposisi bahan pembawa (carrier), ketersediaan bahan organik tanah, serta dosis dan teknik aplikasi pupuk hayati (Santos et al., 2019). Metode aplikasi pupuk hayati pada jagung dapat dilakukan dengan mencampurkannya dengan benih atau mengaplikasikannya di tanah yang akan berkaitan dengan keberhasilan kolonisasi bakteri pada tanaman inang (Berger et al., 2018). Tujuan percobaan ini adalah untuk mengkaji teknik aplikasi pupuk hayati dalam meningkatkan ketersediaan hara sehingga tanaman dapat menyerap hara lebih optimal di tanah Inceptisol.

\section{Bahan dan Metode}

Percobaan pot dilaksanakan di Lahan Percobaan milik Laboratorium Kesuburan Tanah dan Nutrisi Tanaman Fakultas Pertanian Universitas Padjadjaran. Tanah yang digunakan sebagai media tanam adalah ordo Inceptisol Jatinangor yang memiliki tekstur liat, $\mathrm{pH}$ agak masam $(6,48)$, kandungan C-organik dengan kriteria tinggi $(5,05 \%)$, kandungan $\mathrm{N}$ total dengan kriteria sedang $(0,42 \%)$, dan $\mathrm{P}$ tersedia dengan kriteria rendah $(6,49 \mathrm{ppm})$. Bahan lain yang digunakan adalah benih jagung varietas BISI-2, pupuk hayati padat dengan bahan pembawa campuran gambut dan kompos (1:1) yang mengandung isolat BPN (Azotobacter chroococcum dan Azospirillum sp. dengan populasi $2,80 \times 10^{9}$ dan $1,80 \times 10^{7} \mathrm{CFU} \mathrm{g}^{-1}$ ) dan isolat MPF (Pseudomonas malei dan Bacillus

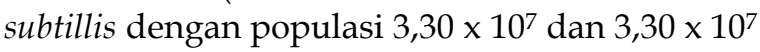
CFU $\mathrm{g}^{-1}$ ), pupuk kandang sapi dengan dosis 2 ton ha-1, pupuk urea $(225 \mathrm{~kg} / \mathrm{ha})$, SP-36 (112,3 $\mathrm{kg} / \mathrm{ha}$ dan $\mathrm{KCl}(37,5 \mathrm{~kg} / \mathrm{ha})$.

Rancangan yang digunakan yaitu Rancangan Acak Kelompok (RAK) yang terdiri dari sembilan perlakuan dan diulang tiga kali. Perlakuan pupuk hayati terdiri dari tanpa aplikasi pupuk hayati (kontrol), perlakuan benih $500 \mathrm{~g} / \mathrm{ha}$, perlakuan benih $250 \mathrm{~g} / \mathrm{ha}$, aplikasi ke dalam tanah $50 \mathrm{~kg} / \mathrm{ha}$, aplikasi ke dalam tanah $25 \mathrm{~kg} / \mathrm{ha}$, perlakuan benih $500 \mathrm{~g} / \mathrm{ha}+$ aplikasi ke dalam tanah $25 \mathrm{~kg} / \mathrm{ha}$, perlakuan benih 250 $\mathrm{g} / \mathrm{ha}+$ aplikasi ke dalam tanah $50 \mathrm{~kg} / \mathrm{ha}$, perlakuan benih $500 \mathrm{~g} / \mathrm{ha}+$ aplikasi ke dalam 
tanah $50 \mathrm{~kg} / \mathrm{ha}$, dan perlakuan benih $250 \mathrm{~g} / \mathrm{ha}+$ aplikasi ke dalam tanah $25 \mathrm{~kg} / \mathrm{ha}$. Parameter yang diamati adalah serapan $\mathrm{N}$ dan $\mathrm{P}$ yang dianalisis pada fase vegetatif akhir (56 hari) serta bobot tongkol per tanaman. Serapan $\mathrm{N}$ dianalisis dengan metoda Kjeldahl dan serapan $\mathrm{P}$ dianalisis dengan cara pengabuan basah (Sulaeman et al., 2005). Analisis statistik dilakukan pada perbedaan nilai rata-rata antar perlakuan dengan menggunakan uji Duncan pada taraf nyata $5 \%$.

\section{Hasil dan Pembahasan}

Serapan $\mathbf{N}$ dan $\mathbf{P}$ Tanaman. Aplikasi pupuk hayati dengan metode perlakuan benih dan aplikasi ke dalam tanah serta kombinasinya berpengaruh nyata terhadap serapan hara $\mathrm{N}$ dan $\mathrm{P}$ tanaman jagung (Tabel 1). Serapan nitrogen paling besar terdapat pada perlakuan kombinasi perlakuan benih (500 g/ha) + aplikasi ke dalam tanah $(50 \mathrm{~kg} / \mathrm{ha})$, sedangkan serapan $\mathrm{N}$ yang paling rendah pada perlakuan tanpa aplikasi pupuk hayati (kontrol). Hal ini menunjukkan bahwa pemberian pupuk hayati mampu meningkatkan kandungan $\mathrm{N}$ tanah sehingga mampu meningkatkan $\mathrm{N}$ yang diserap tanaman. Rasyid et al. (2010) menyatakan bahwa besarnya jumlah nitrogen yang diberikan akan mempengaruhi kadar nitrogen dalam tanaman.

Aplikasi pupuk hayati melalui kombinasi pada benih dan perlakuan ke dalam tanah lebih baik dibandingkan hanya pada benih atau perlakuan pada tanah saja. Hal ini disebabkan pemberian pupuk hayati yang dilakukan pada tanah dan benih akan semakin meningkatkan populasi bakteri di daerah rhizosfer. Hal tersebut sejalan dengan hasil penelitian Gou et al. (2020) bahwa aplikasi pupuk hayati mampu meningkatkan jumlah dan biodiversitas mikroba di rhizosfer. Peningkatan jumlah mikroba akibat penambahan pupuk hayati yang mengandung bakteri pemfiksasi nitrogen mampu meningkatkan $\mathrm{N}$ tanah sehingga serapan $\mathrm{N}$ oleh tanaman menjadi lebih tinggi. Hal ini didukung oleh hasil penelitian Medhat et al. (2011) bahwa aplikasi pupuk hayati yang mengandung Azotobacter sp. dan Azospirillum sp. mampu meningkatkan serapan hara $\mathrm{N}$ pada tanaman karena kemampuan kedua bakteri tersebut dalam menambat $\mathrm{N}$.

Aplikasi pupuk hayati yang mengandung bakteri pemfiksasi $\mathrm{N}$ dan pelarut $\mathrm{P}$ mempengaruhi serapan $\mathrm{P}$ tanaman jagung. Aplikasi pupuk hayati pada benih dan tanah lebih meningkatkan serapan P tanaman dibandingkan dengan perlakuan metode perlakuan benih atau aplikasi ke dalam tanah saja. Aplikasi pupuk hayati metode perlakuan benih $500 \mathrm{~g} / \mathrm{ha}$ ditambah aplikasi ke dalam tanah $50 \mathrm{~kg} / \mathrm{ha}$ atau ditambah aplikasi ke dalam tanah $25 \mathrm{~kg} / \mathrm{ha}$ berbeda nyata dalam meningkatkan serapan $\mathrm{P}$ tanaman dibandingkan dengan perlakuan perlakuan benih saja sebanyak $250 \mathrm{~g} / \mathrm{ha}$ dan perlakuan tanpa pupuk hayati (Tabel 1). Aplikasi benih $500 \mathrm{~g} / \mathrm{ha}+$ aplikasi ke dalam tanah $50 \mathrm{~kg} / \mathrm{ha}$ meningkatkan serapan $\mathrm{P}$ tanaman paling tinggi dibanding perlakuan lainnya, yaitu 21,45 mg.

Peningkatan serapan $\mathrm{P}$ pada tanaman dipengaruhi oleh ketersediaan $\mathrm{P}$, penyebaran akar, dan kemampuan akar dalam menyerap P. Hakim (2006) mengungkapkan bahwa serapan P sangat tergantung pada kontak akar dengan $\mathrm{P}$ dalam larutan tanah. Sebaran akar di dalam

Tabel 1. Serapan N dan P yang dipengaruhi oleh teknik aplikasi pupuk hayati.

\begin{tabular}{lcc}
\hline \multicolumn{1}{c}{ Perlakuan Pupuk Hayati } & $\begin{array}{c}\text { Serapan N } \\
\text { (mg/tanaman) }\end{array}$ & $\begin{array}{c}\text { Serapan P } \\
\text { (mg/tanaman) }\end{array}$ \\
\hline (A) Kontrol (tanpa pupuk hayati) & $1.68 \mathrm{a}$ & $11.25 \mathrm{a}$ \\
(B) Perlakuan benih (500 g/ha) & $1.98 \mathrm{bcd}$ & $15.39 \mathrm{bc}$ \\
(C) Perlakuan benih (250 g/ha) & $1.90 \mathrm{abc}$ & $14.14 \mathrm{ab}$ \\
(D) Aplikasi ke dalam tanah (50 kg/ha) & $1.90 \mathrm{abc}$ & $15.12 \mathrm{bc}$ \\
(E) Aplikasi ke dalam tanah (25 kg/ha) & $1.75 \mathrm{ab}$ & $15.76 \mathrm{bc}$ \\
(F) perlakuan benih (500 g/ha) + aplikasi ke dalam tanah $(25 \mathrm{~kg} / \mathrm{ha})$ & $2.18 \mathrm{~d}$ & $18.42 \mathrm{c}$ \\
(G) perlakuan benih (250 g/ha) + aplikasi ke dalam tanah $(50 \mathrm{~kg} / \mathrm{ha})$ & $2.06 \mathrm{~cd}$ & $17.65 \mathrm{c}$ \\
(H) perlakuan benih (500 g/ha) + aplikasi ke dalam tanah $(50 \mathrm{~kg} / \mathrm{ha})$ & $2.54 \mathrm{e}$ & $21.45 \mathrm{~d}$ \\
(I) perlakuan benih (250 g/ha) + aplikasi ke dalam tanah $(25 \mathrm{~kg} / \mathrm{ha})$ & $2.22 \mathrm{~d}$ & $17.84 \mathrm{c}$ \\
\hline
\end{tabular}

Keterangan: Nilai rata-rata perlakuan pada kolom yang sama yang diikuti oleh huruf yang sama menunjukkan tidak berbeda nyata berdasarkan uji jarak berganda Duncan pada taraf nyata $5 \%$. 
tanah sangat penting dalam meningkatkan serapan P dan bobot kering tanaman. Selain itu, pengambilan $\mathrm{P}$ oleh akar tanaman jagung dipengaruhi oleh sifat akar dan sifat tanah dalam menyediakan P. Suleman et al. (2018) melaporkan bahwa tanaman gandum yang diinokulasi dengan bakteri Pseudomonas sp. MS16 dan Enterobacter sp. sebagai pelarut fosfat dapat meningkatkan $80 \%$ serapan fosfat dibandingkan dengan kontrol. Kemampuan bakteri pelarut $\mathrm{P}$ dalam pupuk hayati untuk melarutkan fosfat dapat meningkatkan serapan $P$ pada tanaman. Liang et al. (2020) menyatakan bahwa bakteri pelarut $\mathrm{P}$ berperan penting dalam peningkatan ketersediaan $\mathrm{P}$ tanah. Hal ini sesuai dengan data penelitian yang telah diperoleh.

Hasil Tanaman. Hasil percobaan menunjukkan bahwa pemberian pupuk hayati yang mengandung bakteri pemfiksasi $\mathrm{N}$ (Azotobacter chroococcum dan Azospirillum sp.) serta bakteri pelarut P (Pseudomonas malei dan Bacillus subtillis) mampu meningkatkan hasil jagung hingga 126,3\% dibandingkan dengan kontrol. Analisis statistik menunjukkan bahwa hasil jagung (bobot tongkol tanpa kelobot) terbaik diperoleh dari perlakuan perlakuan benih $250 \mathrm{~g} / \mathrm{ha}+$ aplikasi ke dalam tanah 25 $\mathrm{kg}$ /ha dengan hasil sebesar 151,01 g per tanaman (Tabel 2) .

Tabel 2. Hasil tanaman jagung yang dipengaruhi oleh teknik aplikasi pupuk hayati

Perlakuan Hasil tanaman

(A) Kontrol (tanpa pupuk hayati)

(g per tanaman)

(B) Perlakuan benih (500 g/ha)

(C) Perlakuan benih (250 g/ha)

$18.17 \mathrm{bc}$

(D) Aplikasi ke dalam tanah (50

$84.10 \mathrm{a}$

$\mathrm{kg} / \mathrm{ha}$

(E) Aplikasi ke dalam tanah 25

$\mathrm{kg} / \mathrm{ha}$ )

(F) perlakuan benih (500 g/ha) +

aplikasi ke dalam tanah $(25 \mathrm{~kg} / \mathrm{ha})$

(G) perlakuan benih $(250 \mathrm{~g} / \mathrm{ha})+$

aplikasi di tanah $(50 \mathrm{~kg} / \mathrm{ha})$

$(\mathrm{H})$ perlakuan benih $(500 \mathrm{~g} / \mathrm{ha})+$

aplikasi ke dalam tanah (50 kg/ha)

(I) perlakuan benih $(250 \mathrm{~g} / \mathrm{ha})+$

aplikasi ke dalam tanah (25 kg/ha)

$110.79 \mathrm{abc}$

$89.60 \mathrm{ab}$

$136.60 \mathrm{~cd}$

153.14 de

180.58 e

Keterangan: Nilai rata-rata perlakuan yang diikuti oleh huruf yang dan pada kolom yang samamenunjukkan tidak berbeda nyata berdasarkan uji jarak berganda Duncan pada taraf nyata $5 \%$.
Peningkatan produksi hasil jagung dengan perlakuan pupuk hayati diperkirakan terjadi karena terjadinya adanya keseimbangan hara baik di dalam tanah yang dikarenakan disebabkan kinerja bakteri pemfiksasi $\mathrm{N}$ dan pelarut $\mathrm{P}$ dalam memfasilitasi ketersediaan hara. Menurut Gardner et al. (1991) menyatakan bahwa apabila unsur $\mathrm{P}$ diserap sesuai batas keseimbangan hara maka akan menaikkan meningkatkan penyerapan unsur hara lainnya. Pada kondisi tersebut akan menyebabkan laju fotosintesis dan pembentukkan karbohidrat meningkat, sehingga hasil tanaman pun akan meningkat. Wang et al. (2019) melaporkan bahwa aplikasi bakteri pemfiksasi N (Azotobacter chroococcum dan Azospirillum brasilence) serta bakteri pelarut $\mathrm{P}$ (Bacillus megaterium dan Pseudomonas fluorescens) mampu meningkatkan ketersediaan hara, dan serapan $\mathrm{N}$, dan $\mathrm{P}$, serta pertumbuhan Cyclocarya paliurus. Percobaan pot dilakukan oleh Mudenoor et al. (2007), untuk mempelajari pengaruh perlakuan pupuk hayati Azospirillum sp. pada bahan kering produksi dan hasil jagung di Karnataka dan hasilnya menunjukkan peningkatan tinggi tunas dan bobot kering akar.

Menurut Fitriatin dan Simarmata (2005) menyebutkan bahwa aplikasi BPF MPF melalui benih akan memungkinkan mikroba tersebut melakukan kontak dengan tanaman lebih awal dan mendominasi rhizosfeir tanaman tersebut. Pengaruh efek aplikasi benihperlakuan benih ini kemungkinan berhubungan dengan efisiensi dalam suplai bahan bagi pertumbuhan tanaman melalui penambatan nitrogen udara, pelarutan fosfor, dan mempengaruhi eksudat dari beberapa senyawa hormonal, seperti sitokinin dan auksin, yang dapat menstimulir serapan hara dan proses fotosintesis menjadi lebih baik yang pada akhirnya akan meningkatkan pertumbuhan dan hasil tanaman. Dengan peningkatan hasil tanaman melalui aplikasi pupuk hayati,

Percobaan pot dilakukan oleh Mudenoor et al. (2007), untuk mempelajari pengaruh perlakuan pupuk hayati Azospirillum sp. pada bahan kering produksi dan hasil jagung di Karnataka dan hasilnya menunjukkan peningkatan tinggi tunas dan bobot kering akar. Dalam hal ini iinokulan mikroba merupakan alternatif untuk mengurangi penggunaan pupuk kimia. Selain itu, inokulan mikroba tidak menimbulkan bahaya lingkungan dan menjaga kesehatan tanah. 


\section{Kesimpulan}

Teknik aplikasi pupuk hayati mempengaruhi serapan hara dan hasil tanaman jagung. Kombinasi aplikasi pupuk hayati pada benih dan juga ke dalam tanah lebih baik pengaruhnya dalam peningkatan serapan hara serta hasil tanaman dibandingkan perlakuan hanya pada benih atau aplikasi ke dalam tanah saja. Perlakuan benih $500 \mathrm{~g} \mathrm{ha}^{-1}+$ aplikasi ke dalam tanah $50 \mathrm{~kg} \mathrm{ha}^{-}$ ${ }^{1}$ meningkatkan serapan $\mathrm{N}$ dan $\mathrm{P}$ tanaman jagung paling baik, sedangkan perlakuan benih $250 \mathrm{~g} \mathrm{ha}^{-1}$ + aplikasi ke dalam tanah $25 \mathrm{~kg} \mathrm{ha}^{-1}$ merupakan aplikasi terbaik dalam meningkatkan hasil tanaman jagung pada tanah Inceptisols.

\section{Ucapan Terima Kasih}

Penelitian ini didanai oleh Kemenristekdikti dengan skema Penelitian Terapan (Nomor Kontrak: 1827/UN6.3.1/LT/2020). Ucapan terima kasih disampaikan kepada Rektor UNPAD, Dekan Fakultas Pertanian, dan Direktur Riset dan Pengadian Kepada Masyarakat UNPAD atas dukungan dan kerjasamanya. Ucapan terima kasih kami sampaikan kepada saudara Fardian Khairul Hakim yang telah banyak membantu pelaksanaan penelitian ini serta semua pihak yang telah membantu kelancaran penelitian ini.

\section{Daftar Pustaka}

Abdurachman, A., A. Dariah, dan A. Mulyani. 2008. Strategi dan teknologi pengelolaan lahan kering mendukung pengadaan pangan nasional. Jurnal Litbang, 27(2).

Bhardwaj, D., M.W. Ansari, R.K. Sahoo and N. Tuteja. 2014. Biofertilizers function as key player in sustainable agriculture by improving soil fertility, plant tolerance and crop productivity. Microbial Cell Factories. 13:66. http://www.microbialcellfactories. com/content/ 13/1/66

Berger, B., S. Patz, S. Ruppel, K. Dietel, S. Faetke, H. Junge, and M. Becker. 2018. Successful formulation and application of plant growth-promoting kosakonia radicincitans in maize cultivation. BioMed Research International. Article ID 6439481, https://doi.org/10.1155/2018/6439481
Fitriatin, B.N. dan T. Simarmata. 2005. Efek metode perlakuan benih dengan kinetin dan suspensi bakteri pelarut fosfat penghasil fitohormon terhadap pertumbuhan dan hasil tanaman padi gogo. Agrikultura 16(2) : $84-88$.

Gardner, F.P., R.B. Pearce, dan R.L. Mitchell. 1991. Fisiologi Tanaman Budidaya. Terjemahan: Herawati Susilo. UI Press.

Gou, J.Y., S.Z. Suo, K.Z. Shao, Q. Zhao, D. Yao, H.P. Li, J.L. Zhang, and C. Rensing. 2020. Biofertilizers with beneficial rhizobacteria improved plant growth and yield in chili (Capsicum annuum L.). World Journal of Microbiology and Biotechnology. 36 : 86.

Hakim, N. 2006. Pengelolaan kesuburan tanah masam dengan teknologi pengapuran terpadu. Padang: Universitas Andalas.

Kasno, Antonius. 2009. Respon tanaman jagung terhadap pemupukan fosfor pada Typic Dystrudepts. J. Tanah Trop., 14 (2): 111-118.

Liang, J., J. Liu, P. Jia, T. Yang, Q. Zeng, S. Zhang, B. Liao, W. Shu, and J. Li. 2020. Novel phosphate-solubilizing bacteria enhance soil phosphorus cycling following ecological restoration of land degraded by mining. The ISME Journal . 14:1600-1613 https://doi.org/10.1038/s41396-020-0632-4

Mącik, M., A. Gryta, and M. Frąc. 2020. Chapter Two - Biofertilizers in agriculture: An overview on concepts, strategies and effects on soil microorganisms. Advances in Agronomy. 162: 31-87

Medhat, Y., Abou-Zeid, and M.A.A. Bakry. 2011. Intregated effect of bio-organic manures and mineral fertilizers on potato productivity and the fertility status of a calcareous soil. Australian Journal of Basic and Applied Sciences. 5(8): 1385-1399.

Mudenoor, M.G., G. Geete, and V.P. Savalgi. 2007. Response of maize (Zea mays) to seed treatment of micronutrients supplemental Azospirillum biofertiilizer. International Journal of Plant Science. 2: 197-201.

Rashid, M., S. Khalil, N. Ayub, S. Alam, and F. Latif. 2004. Organic acid production and phosphate solubilisation by Phosphate Solubilizing Microorganism (PSM) under in vitro conditions. Pakisatan Journal of Biological Sciences. 7 (2): 187 - 196.

Rasyid. 2010. Serapan N Tanaman Akibat Pemberian Pupuk Azolla. Jurnal Agoland, 16(4). 
Santos, M.S., M.A. Nogueira and M. Hungria. 2019. Microbial inoculants: reviewing the past, discussing the present and previewing an outstanding future for the use of benefcial bacteria in agriculture. AMB Express. 9:205 https://doi.org/10.1186/s13568-019-0932-0

Sulaeman, Suparto, dan Eviati. 2005. Analisis Kimia Tanah, Tanaman, Air dan Pupuk. Balai Penelitian Tanah dan Pengembangan Penelitian, Departemen Pertanian.

Suleman,M., S. Yasmin, M. Rasul, M. Yahya, B.M. Atta, and M.S.Mirza. 2018. Phosphate solubilizing bacteria with glucose dehydrogenase gene for phosphorus uptake and beneficial effects on wheat. PLOS ONE. https://doi.org/10.1371/ journal.pone.0204408 September 21
Sumbul, A., R.A. Ansari, R. Rizvi, and I. Mahmood. 2020. Azotobacter: A potential biofertilizer for soil and plant health management. Saudi J Biol Sci. 27(12): 3634-3640.

Walpola, B.C. and M.H. Yoon. 2013. Isolation and characterization of phosphate solubilizing bacteria and their coinoculation efficiency on tomato plant growth and phosphorous uptake. African Journal of Microbiology Research Vol. 7(3), pp. 266-275,

Wang, Z., Z. Chen, Z. Xu, and X. Fu. 2019. Effects of Phosphate-Solubilizing Bacteria and N2-fixing Bacteria on Nutrient Uptake, Plant Growth, and Bioactive Compound Accumulation in Cyclocarya paliurus (Batal.) Iljinskaja. Forests. 10, 772. doi:10.3390/ f10090772 